\title{
Modulatory Actions of Dopamine on NMDA Receptor-Mediated Responses Are Reduced in $D_{1 A}$-Deficient Mutant Mice
}

\author{
Michael S. Levine,${ }^{1}$ Katharine L. Altemus, ${ }^{1}$ Carlos Cepeda, ${ }^{1}$ Howard C. Cromwell, ${ }^{1}$ Cynthia Crawford, ${ }^{1}$ \\ Marjorie A. Ariano, ${ }^{2}$ John Drago, ${ }^{3}$ David R. Sibley, ${ }^{4}$ and Heiner Westphal ${ }^{5}$ \\ ${ }_{1}^{1}$ Mental Retardation Research Center, University of California, Los Angeles, Los Angeles, California 90024-1759, \\ 2Department of Neuroscience, The Chicago Medical School, North Chicago, Illinois 60064, 3Anatomy Department, \\ Monash University, Clayton, Victoria 3168, Australia, ${ }^{4}$ Experimental Therapeutics Branch, National Institute of \\ Neurological Disorders and Stroke, Bethesda, Maryland 20892, and 5 Laboratory of Mammalian Genes and Development, \\ National Institutes of Child Health and Human Development, Bethesda, Maryland 20892
}

The role of $D_{1}$ dopamine (DA) receptors in mediating the ability of DA to modulate responses attributable to activation of NMDA receptors was examined in mice lacking $D_{1 A}$ dopamine receptors. Specifically, experiments were designed to test the hypothesis that the ability of DA to potentiate responses mediated by activation of NMDA receptors was attributable to activation of $D_{1}$ receptors. Based on this hypothesis, we would predict that in the $D_{1 A}$ mutant mouse, either DA would not induce enhancement of NMDA-mediated responses, or the enhancement would be severely attenuated. The results provided evidence to support the hypothesis. In mutant mice, DA and $D_{1}$ receptor agonists did not potentiate responses mediated by activation of NMDA receptors. In contrast, in control mice, both $D A$ and $D_{1}$ receptor agonists markedly potentiated responses mediated by activation of NMDA receptors. The effects of DA in attenuating responses mediated by activation of non-NMDA receptors also were altered in the mutant, suggesting that this action of DA may require coupling or interactions between $D_{1}$ and $D_{2}$ receptors. The present studies also provided an opportunity to assess some of the basic electrophysiological and morphological properties of neostriatal neurons in mice lacking $D_{1 A}$ DA receptors. Resting membrane potential, action potential parameters, input resistance, excitability, somatic size, dendritic extent, and estimates of spine density in mutants and controls were similar, suggesting that these basic neurophysiological and structural properties have not been changed by the loss of the $D_{1 A}$ DA receptor.

Key words: dopamine receptors; $D_{1}$; excitatory amino acid receptors; knock-out mice; mutant; neostriatal slices; NMDA
There is considerable interest in understanding the functional interactions between dopamine (DA) and excitatory amino acid (EAA) neurotransmission in the neostriatum. It is well known that EAAs and DA have many potential sites for physiological interactions in the neostriatum and that a close morphological association exists between the glutamate-containing and DAcontaining inputs (Bouyer et al., 1984; Freund et al., 1984; Smith and Bolam, 1990). The glutamate-containing inputs make synaptic contacts on the heads of spines, whereas the DA-containing inputs synapse on spine necks, dendritic shafts, and cell bodies (Smith and Bolam, 1990; Seasack et al., 1994).

We have studied some of the factors involved in determining how DA and EAAs interact in the neostriatum and neocortex (Cepeda et al., 1992b, 1993; Levine et al., 1995, 1996; Altemus and Levine, 1996). We have primarily examined the hypothesis that the combination of subtypes of EAA and DA receptors activated determines the direction of subsequent DA modulation. We recently reported that DA potentiates responses mediated by acti-

Received May 6, 1996; revised June 24, 1996; accepted June 25, 1996.

This work was supported by U.S. Public Health Service Grants NS 35233, AG 10252, and HD05958 (M.S.L.) and NS 33277 (M.A.A.). J.D. is the recipient of a Basser Travelling Fellowship from the Royal Australasian College of Physicians and is supported by the Australian National Health and Medical Research Council. We thank Q. Yu for assistance in preparation of brain slices. We thank Abbott Pharmaceuticals for supplying the A-77636.

Correspondence should be addressed to Michael S. Levine, Mental Retardation Research Center, 760 Westwood Plaza, University of California, Los Angeles, Los Angeles, CA 90024-1759.

Copyright (C) 1996 Society for Neuroscience $0270-6474 / 96 / 165870-13 \$ 05.00 / 0$ vation of NMDA receptors, but attenuates responses mediated by activation of non-NMDA receptors in neocortex (Cepeda et al., 1992b) and neostriatum (Cepeda et al., 1993; Levine et al., 1995, 1996). The effects of DA on responses mediated by NMDA receptor activation were mimicked by application of a $D_{1}$ receptor agonist and were blocked by a $\mathrm{D}_{1}$ antagonist, whereas the effects of DA on responses mediated by non-NMDA receptor activation were mimicked by application of a $\mathrm{D}_{2}$ receptor agonist.

The recent development of DA receptor gene-targeted mutant mice lacking specific receptor subtypes offers additional opportunities to test hypotheses concerning functional interactions among DA and EAA receptors. Mutant mice lacking $\mathrm{D}_{1 \mathrm{~A}}, \mathrm{D}_{2}$, and $\mathrm{D}_{3} \mathrm{DA}$ receptors have been generated (Drago et al., 1994; Xu et al., 1994a,b, 1995; Balk et al., 1995; Accili et al., 1996). Although the $\mathrm{D}_{2}$ mutant has been reported to be cataleptic (Balk et al., 1995), mice lacking $\mathrm{D}_{1 \mathrm{~A}}$ or $\mathrm{D}_{3}$ receptors appear hyperactive (Xu et al., 1994a,b; Miner et al., 1995; Accili et al., 1996) or display behavioral changes such as a marked lack of rearing (Drago et al., 1994). The present experiments were designed to use the $\mathrm{D}_{1 \mathrm{~A}}$ mutant to further examine the hypothesis that DA-induced enhancement of responses mediated by activation of NMDA receptors in the neostriatum is attributable to activation of $\mathrm{D}_{1}$ receptors. We would predict that in the $\mathrm{D}_{1 \mathrm{~A}}$ mutant, DA would not induce enhancement of NMDA-mediated responses, or that enhancement would be severely attenuated. The present studies also provide an opportunity to assess some of the basic electrophysiological and morphological properties of neostriatal neurons in mice lacking $\mathrm{D}_{1 \mathrm{~A}}$ DA receptors. 


\section{MATERIALS AND METHODS}

\section{Animals}

All procedures were performed in accordance with the U.S. Public Health Service Guide for Care and Use of Laboratory Animals and were approved by the Institutional Animal Care and Use Committee at the University of California, Los Angeles (UCLA). Mice with a targeted inactivated $\mathrm{D}_{1 \mathrm{~A}}$ DA receptor gene were obtained from a breeding colony established at the National Institutes of Health (NIH) (Drago et al., 1994). Initially, homozygous $(-/-)$ mice and littermate controls $(+/+)$ were obtained and used in experiments until a parallel breeding colony was established at UCLA. Data from all but 12 animals were obtained from the UCLA colony. There were no consistent differences in results obtained from the UCLA and the NIH colony, and data were pooled.

All animals were housed under standard conditions on a $12 \mathrm{hr}$ light/ dark cycle with food and water available ad libitum. Experiments were performed on both male and female controls $(+/+)$ and homozygous mutant mice $(-/-)$ littermates of at least $80 \mathrm{~d}$ of age. Heterozygous mice were not studied. Multiple experiments were performed on tissue obtained from the same animal by different experimenters on the same day. Typically, experiments were performed on two animals per week, one control and one mutant. To avoid experimenter bias, brain slices were prepared by an individual who did not perform the experiment, and experimenters were not informed of the genotype of the animal until data had been obtained from both animals for each week. The order of experiments performed on mutant or control mice also was randomized for each week.

\section{Genotyping mice}

$\mathrm{D}_{1 \mathrm{~A}}$ receptor knock-out mice were generated from embryonic stem cells in which one of the $\mathrm{D}_{1 \mathrm{~A}}$ receptor alleles was targeted in vitro by homologous recombination (Drago et al., 1994). Briefly, a targeting construct was designed (pKO.3) in which a neomycin phosphotransferase gene was inserted into a region of the $\mathrm{D}_{1 \mathrm{~A}}$ receptor gene encoding the fifth transmembrane domain. In addition, $0.75 \mathrm{~kb}$ of gene sequence downstream of the insertion site was excised. The excised sequence encodes the third intracytoplasmic loop, the removal of which generates an inactive gene product. Positive clones were used to create chimeric mice. Chimeric males were mated with female $\mathrm{C} 57 \mathrm{BL} / 6$ mice to create heterozygotes. Southern analysis was used to identify the genotype of mice (Drago et al., 1994).

\section{$D_{1 A} m R N A$ and protein detection}

To verify morphologically the altered expression of $\mathrm{D}_{1 \mathrm{~A}}$ receptors in the neostriatum, receptor transcript and protein were assessed in tissue slices $(10$ $\mu \mathrm{m})$ from mutant $(n=3)$ and control $(n=3)$ mice. For these analyses, brains were prepared at UCLA, coded, and then shipped to the Chicago Medical School for analysis of mRNA and protein. Decoding was performed after morphological experiments were complete. For mRNA, a primer of 39 mer and $\sim 50 \%$ GC content was synthesized (NBI, Plymouth, MN) for the $\mathrm{D}_{1 \mathrm{~A}}$ DA receptor. The primer used, 5'-GGACATCTTAAAGGAACTTTCAGACTGGGCGCATTCGAC-3', corresponded to a portion of the carboxyl tail and bases 1424-1463 on the sense strand of the transcript (Monsma et al., 1990). In situ transcription followed the protocol described previously (Noblett and Ariano, 1996). Sections were hybridized to the primer overnight, followed by enzymatic extension using reverse transcriptase (Seikagaku, Rockville, MD). Rhodamine-labeled dUTP (Fluorored, Amersham, Arlington Heights, IL) was incorporated into the nascent cDNA/ mRNA heteroduplex to detect transcript expression using routine epifluorescence microscopy. The $\mathrm{D}_{1 \mathrm{~A}}$ DA receptor protein was identified using well-characterized antisera (obtained from RBI, Natick, MA) (Levey et al., 1993; Ariano and Sibley, 1994). Standard immunofluorescent methods were used, and primary anti-receptor antisera were incubated overnight, diluted in PBS, pH 7.2, at 1:1000, detected using Bodipy- or fluorescein-labeled secondary antisera (Molecular Probes, Eugene, OR, or Jackson ImmunoResearch, West Grove, PA). The sections were examined using routine epifluorescence microscopy. The validity of in situ transcription was determined by (1) using oligo-d(T) ${ }_{36}$, which was annealed to all poly $\left(\mathrm{A}^{+}\right)$-tailed mRNA in cells undergoing protein synthesis as a positive control, and (2) demonstrating that omission of reverse transcriptase, fluorescent dUTP, or primer produced a complete loss of signal.

\section{Slice preparation}

Mice were killed for rapid brain extraction, the brains were blocked, and rostral tissue containing the neostriatum was sectioned coronally $(\sim 350$ $\mu \mathrm{m}$ thick). Throughout sectioning, slices were bathed in an oxygenated $\left(95 \% \mathrm{O}_{2} / 5 \% \mathrm{CO}_{2}\right.$ ), low-Ca ${ }^{2+}$, artificial CSF (ACSF) composed of (in mM): $\mathrm{NaCl} 130, \mathrm{KCl} 3, \mathrm{NaH}_{2} \mathrm{PO}_{4} 1.25, \mathrm{MgCl}_{2} 5, \mathrm{NaHCO}_{3} 26, \mathrm{CaCl}_{2} 1$, glucose 10. Slices were incubated in lactated bicarbonate ACSF [same as above, except containing (in mM): $\mathrm{CaCl}_{2} 2, \mathrm{MgCl}_{2} 2$, lactate 4] at $33^{\circ} \mathrm{C}$ for at least $1 \mathrm{hr}$ before being placed in a Haas-type recording chamber.

\section{Intracellular recording}

In the recording chamber, slices were superfused $(1.4 \mathrm{ml} / \mathrm{min})$ with standard ACSF (concentrations in mM: $\mathrm{NaCl} 124, \mathrm{KCl} 5, \mathrm{NaH}_{2} \mathrm{PO}_{4} 1.25$, $\mathrm{MgSO}_{4} 2, \mathrm{NaHCO}_{3} 26, \mathrm{CaCl}_{2}$, glucose 10) or $\mathrm{Mg}^{2+}$-free ACSF containing 6-cyano-7-nitroquinoxaline-2,3-dione (CNQX) $(5 \mu \mathrm{M})$ to block non-NMDA receptors. Slices were perfused for a minimum of $30 \mathrm{~min}$ within the chamber before electrophysiological recording began. This time period was sufficient to produce blockade of responses mediated by non-NMDA receptors (Levine et al., 1996). Glass micropipettes filled with 3 M K-acetate $(60-200 \mathrm{M} \Omega$ ) were used for recording. Signals were amplified (Axoclamp-2A, Axon Instruments, Foster City, CA), displayed on an oscilloscope, and digitized for subsequent computer analysis (pClamp 6.0.1, Axon Instruments). After a neuron was impaled, a baseline recording (20-30 $\mathrm{min}$ ) was obtained to ensure stability of membrane properties. Only data obtained from neurons with resting membrane potentials of at least $-60 \mathrm{mV}$ and action potentials exceeding $55 \mathrm{mV}$ (measured from the start of the rapid rising phase to the peak of the depolarization) were used. All data were obtained from well-impaled neurons in which recordings were made for 1-2 hr. Membrane properties [membrane potential, rheobase (current necessary to elicit an action potential), and input resistance] and action potential characteristics (amplitude and duration at one-half amplitude) were measured during the baseline recording period. Current-voltage relationships were obtained by injection of depolarizing and hyperpolarizing pulses and the cell's input resistance was determined from hyperpolarizing pulses in the linear portion of the current-voltage plots.

\section{Evoking responses mediated by activation of EAA receptor subtypes}

Two methods were used for evoking responses mediated by activation of NMDA receptors. The first method consisted of iontophoretically applying NMDA in the vicinity of the recorded cell in slices bathed in standard ACSF. The second method used local extracellular electrical stimulation to evoke synaptic responses in slices bathed in $\mathrm{Mg}^{2+}$-free ACSF (to remove the voltage-dependent $\mathrm{Mg}^{2+}$ block of the NMDA receptor channel) and CNQX (to block non-NMDA receptor activation). In this condition, locally evoked depolarizing synaptic responses (DPSPs) in the neostriatum are mediated primarily by activation of NMDA receptors (Cherubini et al., 1988; Nisenbaum et al., 1993; Levine et al., 1996). DPSPs also were evoked in slices bathed in standard ACSF. In this condition, responses are mediated primarily by non-NMDA receptors (Herrling, 1985; Cherubini et al., 1988; Nisenbaum et al., 1993; Levine et al., 1996). We verified these findings in the present population of mice by blocking DPSPs in standard ACSF with CNQX $(5 \mu \mathrm{M})$ and in $\mathrm{Mg}^{2+}$-free ACSF with application of both CNQX $(5 \mu \mathrm{M})$ and 2-amino-5phosphonovalerate $(25 \mu \mathrm{M})$ [an NMDA receptor antagonist (data not shown)].

Iontophoresis. The procedures for iontophoresis in the neostriatal slice have been described (Cepeda et al., 1991a, 1993, 1994, 1996). Briefly, NMDA and DA were applied iontophoretically using a multibarreled micropipette positioned close $(100-200 \mu \mathrm{m})$ to the recording electrode with the aid of an optical grid. Pipettes contained NMDA (0.1 M, pH 8), DA $(0.2 \mathrm{M}, \mathrm{pH} 4.5)$, and saline for current balancing and control. Holding currents of appropriate polarity were 15-20 nA. NMDA was iontophoretically ejected in an ascending series of current intensities until a threshold for inducing action potentials was obtained. Ejection pulse duration varied from 5-15 sec, but was held constant for each cell. The interval between ejection pulses was at least 2 min to avoid cumulative effects of the drugs. Hyperpolarizing current pulses (0.2-0.5 nA, 50-200 msec duration, 0.5 or 1 per sec) were applied through the recording electrode to estimate conductance changes during drug application. Applications of saline (of similar polarity and of equal or greater amplitude than those required to produce effects with NMDA or with DA) never produced effects on membrane or action potentials in the recorded cells (data not shown). In iontophoretic experiments, the effects of DA were measured in standard ACSF. To test the effects of DA or $\mathrm{D}_{1}$ agonists, a single NMDA ejection intensity was chosen (usually near the threshold for inducing action potentials). After a stable baseline response was 
obtained (2-3 applications of NMDA), DA (applied iontophoretically) or a $\mathrm{D}_{1}$ receptor agonist (SKF 38393, 10-20 $\mu \mathrm{M}$ bath application or A-77636, $3 \mu \mathrm{M}$ bath application) was applied. Responses to iontophoretically applied NMDA were reassessed after application of DA or the $\mathrm{D}_{1}$ agonist ceased. Three measures were recorded: maximum response amplitude, response duration at half-maximum amplitude, and response area (amplitude $\times$ half-amplitude duration). Area was used as a response measure, because subpopulations of cells displayed changes in amplitude or duration but not in both measures and, thus, the area measurement incorporated information from both measures (Levine et al., 1996).

Evoked synaptic responses. The stimulating electrode used to evoke DPSPs consisted of a pair of $0.1 \mathrm{~mm}$ diameter Teflon-coated silver wires (exposed $0.25 \mathrm{~mm}$ at the tips, tips separated by $0.25 \mathrm{~mm}$ ) placed $\sim 1-3 \mathrm{~mm}$ from the recording electrode. One lead was placed in the corpus callosum and the other lead in the dorsal neostriatum or neocortex. Stimuli consisted of constant current $100 \mu \mathrm{sec}$ square wave pulses of varying amplitudes $(60-2000 \mu \mathrm{A})$. Stimulus frequency was 1 pulse/4-5 sec. The stimulation intensity used to elicit DPSPs was $\sim 50-70 \%$ of the spikeeliciting intensity. DPSP amplitudes were measured from the start of the rising phase to the peak of the depolarization, whereas durations were measured at half-maximum amplitude. Measurements of amplitudes and durations at half-maximum amplitude were obtained from averages of 4-6 responses. In addition to measuring peak amplitude and duration at half amplitude, DPSP area was computed as described above (amplitude $\mathrm{X}$ half-amplitude duration). Measurements were obtained before (baseline), during, and after 15 min exposure to bath-applied DA $(20 \mu \mathrm{M})$ or the $\mathrm{D}_{1}$ agonist SKF $38393(5-20 \mu \mathrm{M})$. Cells were bathed either in standard ACSF or prebathed in $\mathrm{Mg}^{2+}$-free ACSF containing CNQX (5 $\mu \mathrm{M})$. DPSPs reached stable amplitudes and durations after $30 \mathrm{~min}$ in $\mathrm{Mg}^{2+}$-free ACSF with CNQX.

Concentrations for DA and SKF 38393 were chosen based on previous work in producing potentiation of responses mediated by activation of NMDA receptors in rat neostriatum (Levine et al., 1996). In our experience, $20 \mu \mathrm{M}$ DA is a midrange concentration that produces an average $30 \%$ increase in response amplitude and duration and an average $70 \%$ increase in response area. Concentrations for SKF $38393(5-20 \mu \mathrm{M})$ also were based on previous work in the rat (Cepeda et al., 1993; Levine et al., 1996). Concentrations of $10-20 \mu \mathrm{M}$ produced significant increases in response area in almost all rat neostriatal cells. Concentrations of A-77636 (3 $\mu \mathrm{M})$ were based on the literature (Kebabian et al., 1992; Acquas et al., 1994). Although we used various concentrations of agonists, we did not attempt to examine systematically concentration-response relationships between cells or within the same cell (e.g., by performing cumulative response studies).

\section{Cell identification}

In some experiments, electrodes were filled with $2 \%$ biocytin (Sigma, St. Louis, MO) in $3 \mathrm{M} \mathrm{K}$-acetate to label cells intracellularly for subsequent identification. Cells were labeled to identify the type of neostriatal neuron and to determine whether there were gross morphological differences between cells from mutants and controls. Biocytin was injected with hyperpolarizing current pulses $(0.5 \mathrm{~Hz}, 0.3-0.6 \mathrm{nA})$. After the experiment, the slice was fixed in $4 \%$ paraformaldehyde overnight, then processed according to published protocols (Horikawa and Armstrong, 1988). Measurements of the three longest dendrites for each labeled neuron (from soma to tip) were obtained using a computer-assisted image analysis system (Micromeasure, Analytical Measuring Concepts, Irvine, CA) to estimate the approximate size of the dendritic field. Only dendrites that were entirely in the plane of the section were measured. In addition, measurements of somatic cross-sectional area and long- and short-axis diameters were obtained for each filled neuron. Although spines were not counted, qualitative estimates of their density were obtained by using four categories: $0=$ none, $1=$ sparse, $2=$ medium density, and 3 = abundant and dense.

\section{Data quantification and statistics}

To compare data between cells and across experimental conditions, differences in amplitudes, durations, and areas of responses in the presence of DA or $\mathrm{D}_{1}$ agonists were converted to percentage change from baseline. For bath-applied $\mathrm{D}_{1}$ agonists, quantitative determinations of percentage changes were based on data obtained at the $10 \mu \mathrm{M}$ concentration, even though some cells were tested with multiple concentrations. There were no differences in changes when NMDA-mediated responses were evoked iontophoretically or synaptically. Thus, for these quantita-
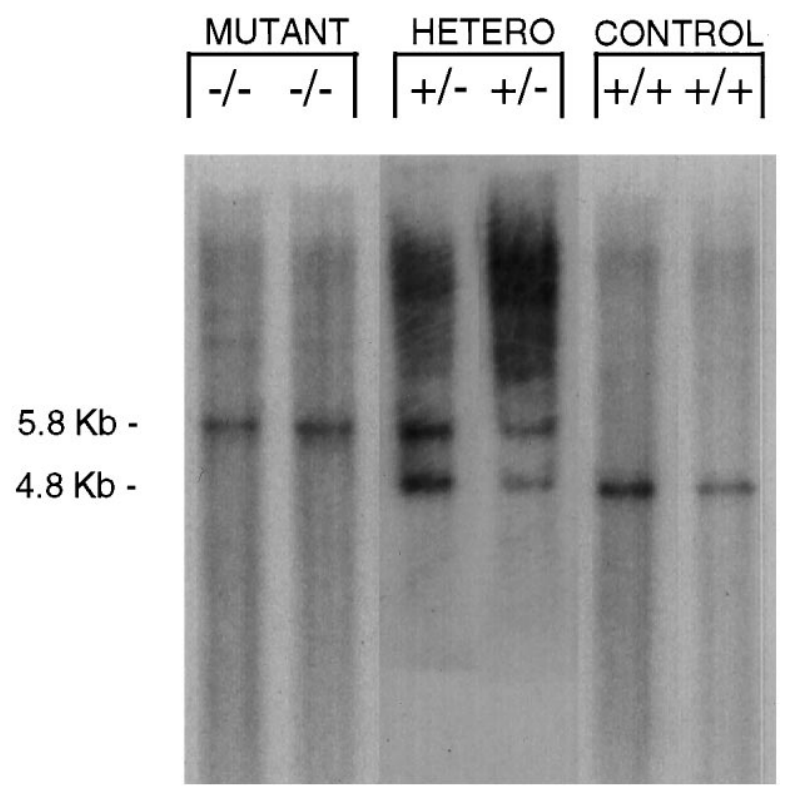

Figure 1. Examples of Southern analyses revealing expected patterns of genotypes from tail-derived DNA from six mice. HindIII digests were probed with probe B (Drago et al., 1994). Left lanes are from two mutants $(-/-)(5.8 \mathrm{~kb})$, middle lanes are from two heterozygotes $(+/-)(4.8$ and $5.8 \mathrm{~kb})$, and right lanes are from two controls $(+/+)(4.8 \mathrm{~kb})$.

tive analyses, percent change data from each of these techniques were combined.

Statistical analyses were performed on both mean and median values for each group. Medians were analyzed because on inspection of distributions of quantitative changes (Fig. 6), it was apparent that marked distributional shifts were occurring. Differences between mean values for experimental and control conditions were assessed with appropriate $t$ tests. Differences between medians were assessed with Mann-Whitney Rank Sum tests. In the text and tables, values are presented as means \pm $\mathrm{SE}$ or medians \pm interquartile ranges. Differences between means and medians for experimental and control conditions were considered statistically significant when $p<0.05$.

\section{RESULTS}

\section{Genotyping, $D_{1 \mathrm{~A}}$ mRNA, and protein detection}

Southern analysis distinguished controls [controls $\left(\mathrm{D}_{1 \mathrm{~A}}+/+\right.$, a single $4.8 \mathrm{~Kb}$ band representing the normal allele), mutant $\left(\mathrm{D}_{1 \mathrm{~A}}\right.$ $-/-$, a $5.8 \mathrm{~Kb}$ band representing the targeted allele), and heterozygotes $\left(\mathrm{D}_{1 \mathrm{~A}}+/-, 4.8\right.$ and $\left.\left.5.8 \mathrm{~Kb}\right)\right]$ (Fig. 1). In morphological experiments, the $\mathrm{D}_{1 \mathrm{~A}}$ DA receptor mRNA was expressed robustly in control neostriatal neurons (Fig. $2 A$ ), whereas the transcripts were completely absent in the mutants (Fig. $2 B$ ). Additionally, the encoded protein was easily detected in the control neostriatum (Fig. 2C), but absent in the mutant (Fig. 2D). When the monoclonal rat antisera (Levey et al., 1993) was used for visualization, spurious cross-recognition of blood vessels by the secondary antirat antisera occurred in the tissue (Fig. 2C,D, arrowheads). The polyclonal anti- $\mathrm{D}_{1 \mathrm{~A}}$ DA receptor antisera (Ariano and Sibley, 1994) showed loss of cell body immunofluorescent protein staining in the mutants as compared with the controls (data not shown).

\section{Electrophysiology}

\section{Membrane properties and DPSPS}

Electrophysiological data were obtained from a total of 92 neurons from mutants and 76 neurons from their control littermates. In general, there were few significant differences in the basic 

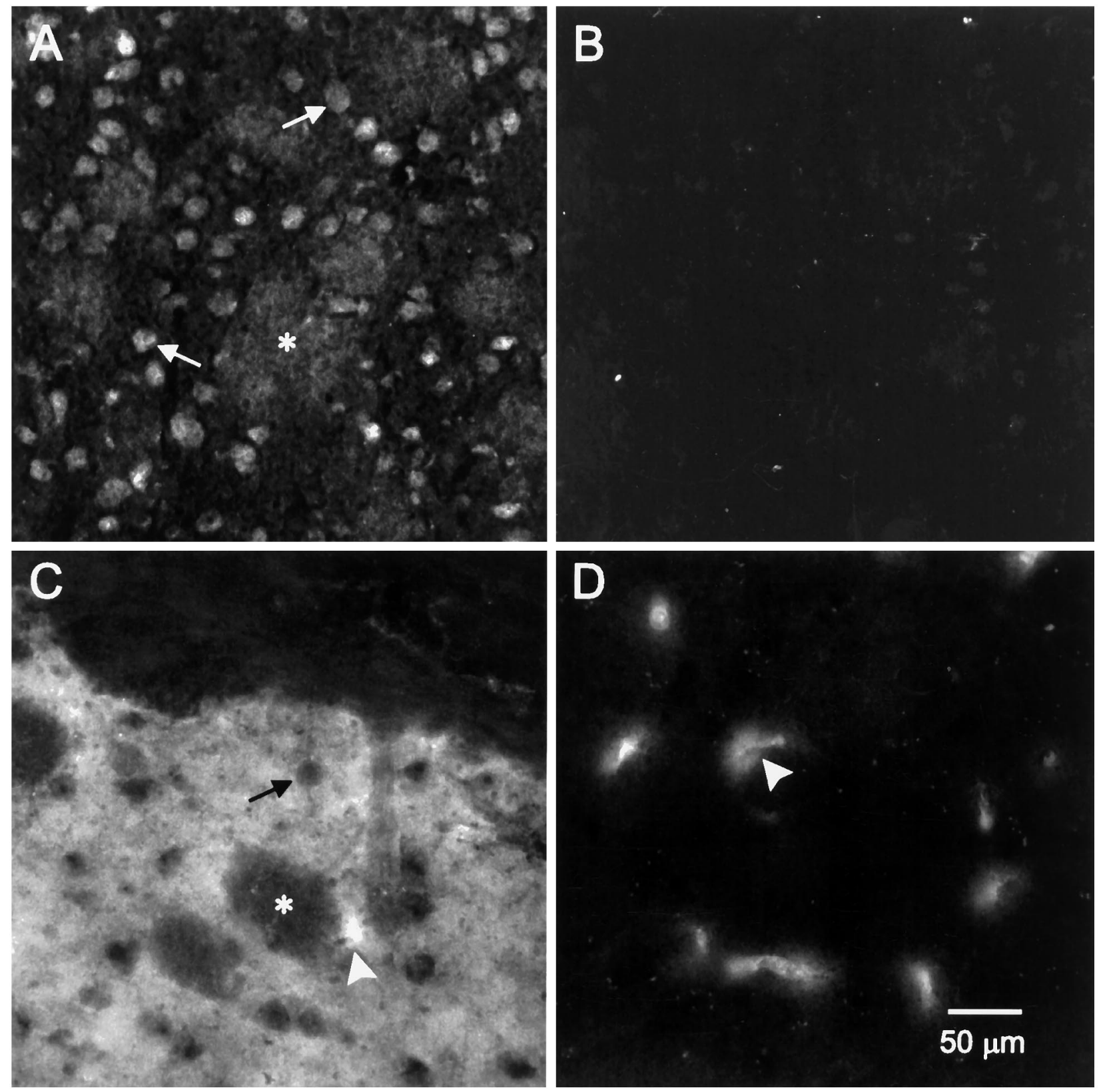

Figure 2. Morphological assessment of $\mathrm{D}_{1 \mathrm{~A}}$ receptor expression in $10-\mu \mathrm{m}$-thick tissue sections in mutant and control neostriatum. All photomicrographs were enlarged and printed using identical parameters so that direct comparisons between controls and mutants can be made. $A$, Transcript for the receptor in the control animal was detected using fluorescent in situ transcription as described in Materials and Methods. Numerous medium-size neurons express robust levels of mRNA for the receptor (arrows). Asterisk indicates myelinated fiber bundles. $B$, Transcript for the receptor is absent in the mutant neostriatum. $C$, Receptor protein staining was present as an intense fluorescence within the neuropil, but was excluded from the somata of medium-size cells (arrow) using the commercial rat monoclonal antibody. The corpus callosum (top) is devoid of immunofluorescence, as are the myelinated fiber bundles that course through the neostriatum (asterisk). Arrowhead points to an immunoreactive blood vessel that is an artifact produced by recognition by the secondary-conjugated goat anti-rat antisera. These appeared in sections from both controls and mutants. $D$, Immunofluorescence for the receptor protein is absent in the mutant animal. The reactive elements are blood vessels (arrowhead).

electrophysiological properties between the two groups. Average resting membrane potentials, average action potential amplitudes and half-amplitude durations, and average rheobases were similar in standard ACSF and $\mathrm{Mg}^{2+}$-free ACSF containing CNQX (Fig. 3; Table 1A). Although average input resistances were similar in standard ACSF, in $\mathrm{Mg}^{2+}$-free ACSF containing CNQX, average input resistances were significantly elevated in mutant mice (Table 1A).

DPSP amplitudes, half-amplitude durations, and areas also were compared in standard and $\mathrm{Mg}^{2+}$-free ACSF containing CNQX. In standard ACSF, only the area of the DPSP was significantly larger in mutant mice compared with controls (Table 1B). When bathed in $\mathrm{Mg}^{2+}$-free ACSF containing CNQX, the duration of the DPSP and its area increased in controls and mutants compared with baseline values obtained for each group in standard ACSF. In $\mathrm{Mg}^{2+}$-free ACSF with CNQX, although both the half-amplitude durations and the areas of the DPSPs were larger in the mutants compared with controls, the differences 
CONTROL MUTANT
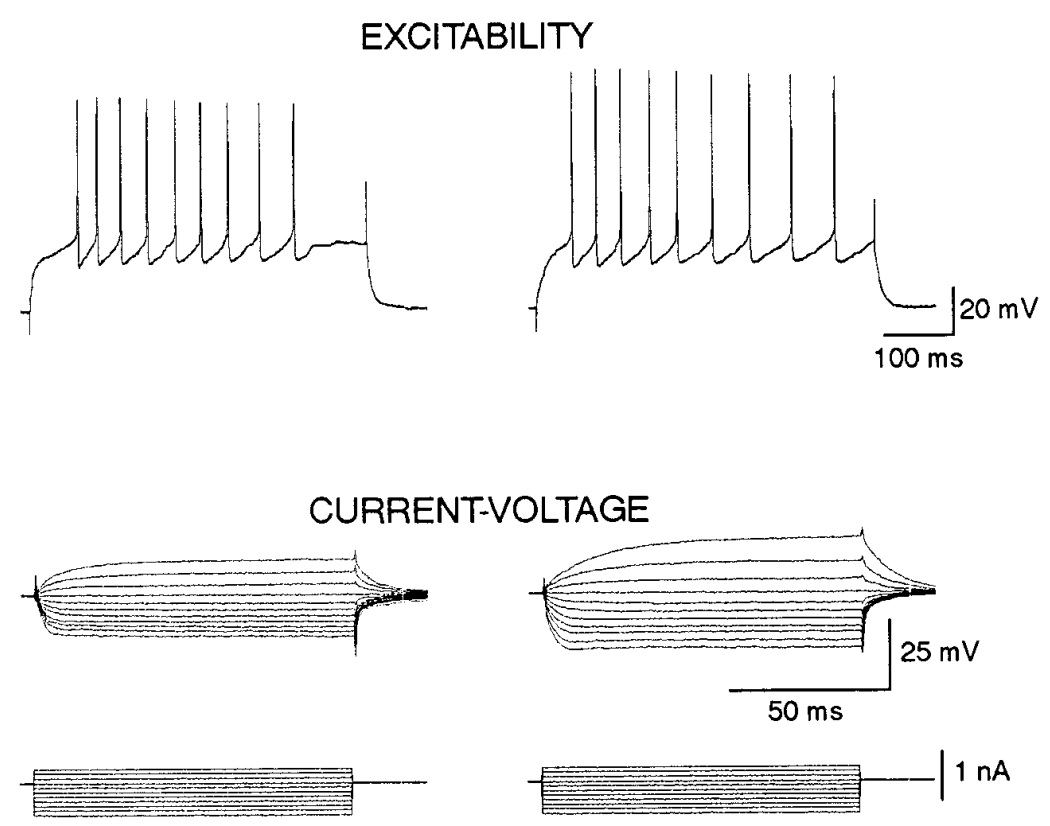

Figure 3. Examples of basic membrane properties. Top traces (EXCITABILITY) show responses to $500 \mathrm{msec}$ depolarizing current pulses capable of generating trains of action potentials in a cell from a control and a cell from a mutant. Middle traces (CURRENT-VOLTAGE) show voltage responses to a series of hyperpolarizing and depolarizing current pulses in the same cells. Bottom graph shows the current-voltage plots derived from the traces. Input resistances $(33.8$ and $29.5 \mathrm{M} \Omega$ for the mutant and control cells, respectively) were calculated from the linear portion of the curves in the hyperpolarizing direction. Resting membrane potentials were $-73 \mathrm{mV}$ for the control cell and $-72 \mathrm{mV}$ for the mutant cell.

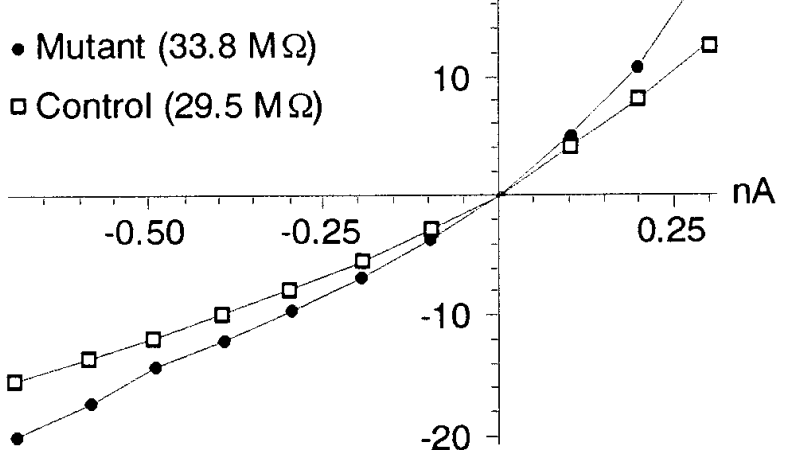

responses induced by NMDA in mutant cells were markedly reduced (Fig. 4). As expected, based on our previous work in rats (Levine et al., 1996), in control mice, SKF 38393 increased the size of DPSPs mediated by activation of NMDA receptors (Fig. 5). However, in mutants, DPSPs mediated by NMDA receptors $\left(\mathrm{Mg}^{2+}\right.$-free $\left.\mathrm{ACSF}+\mathrm{CNQX}\right)$ were not altered consistently by bath application of SKF 38393. At concentrations of $10 \mu \mathrm{M}$, SKF 38393 produced robust increases in the size of DPSPs in control cells (Fig. 5), but minimal increases in mutant cells. Even at higher concentrations of SKF $38393(20 \mu \mathrm{M})$, when increases were induced in mutant cells, they were small (Fig. 5).

As pointed out in Materials and Methods, because there were no differences in the effects of $\mathrm{D}_{1}$ agonists when responses were induced by iontophoretic application of NMDA or evoked synaptically, data (measures of percent change from baseline obtained from iontophoretic evoked depolarizations and from evoked DPSPs) were pooled for quantitative analysis. In controls, percentage of the depolarization and in action potential frequency in all cells tested. In contrast, the effects of $\mathrm{D}_{1}$ agonists on iontophoretic 
Table 1. Basic membrane and DPSP properties

A. Basic membrane properties

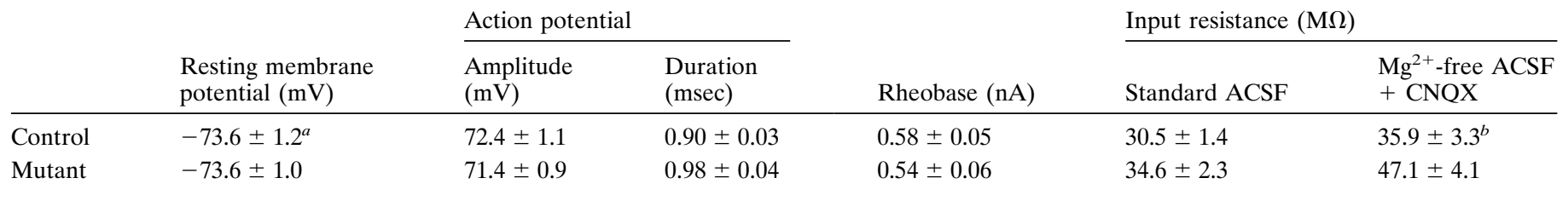

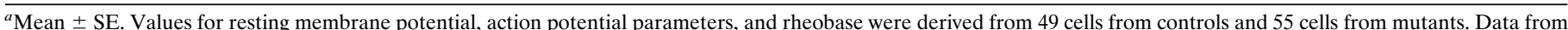

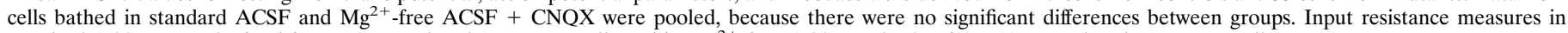
standard ACSF were obtained from 16 control and 17 mutant cells and in $\mathrm{Mg}^{2+}$-free ACSF + CNQX from 13 control and 11 mutant cells.

${ }^{b}$ Difference between means from controls and mutants is statistically significant $(t=2.15$, $\mathrm{df}=22, p=0.0431)$.

B. DPSP amplitude, duration, and area

\begin{tabular}{|c|c|c|c|}
\hline & Amplitude (mV) & $\begin{array}{l}\text { Standard ACSF } \\
\text { duration (msec) }\end{array}$ & Area \\
\hline Control & $12.6 \pm 1.1(n=28)^{a}$ & $12.1 \pm 0.7$ & $149 \pm 13^{b}$ \\
\hline Mutant & $14.6 \pm 0.9(n=29)$ & $\begin{array}{l}13.9 \pm 1.1 \\
\mathrm{Mg}^{2+} \text {-free ACSF }+ \text { CNQX }\end{array}$ & $189 \pm 13$ \\
\hline Control & $11.5 \pm 1.3(n=21)$ & $39.0 \pm 3.6$ & $494 \pm 96$ \\
\hline Mutant & $11.7 \pm 1.3(n=21)$ & $49.4 \pm 4.3$ & $652 \pm 118$ \\
\hline
\end{tabular}

${ }^{a}$ Mean \pm SE. Number for each group is in parentheses.

${ }^{b}$ Difference between means for mutants and controls is statistically significantl $(t=-2.11$, df $=55, p=0.0396)$.

Table 2. Modulation of responses mediated by activation of NMDA receptors

A. Mean percentage change

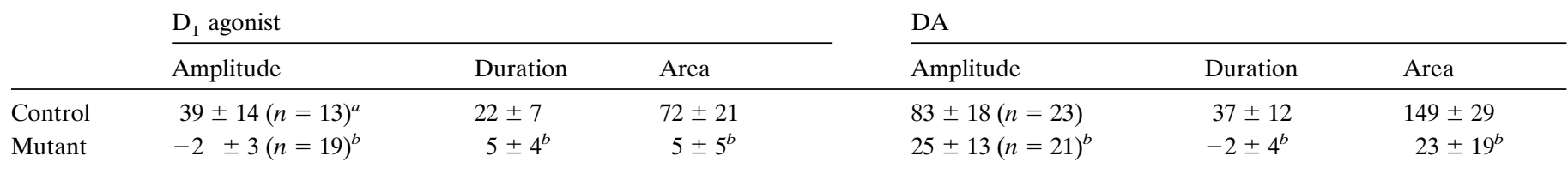

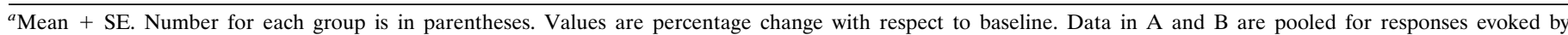
iontophoretic application of NMDA and from DPSPs.

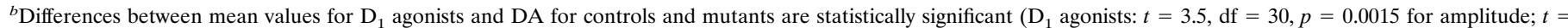

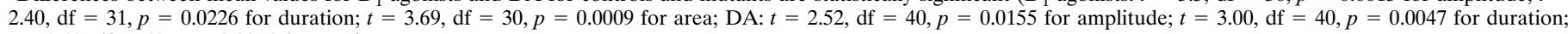
$t=3.43$, df $=40, p=0.0014$ for area).

B. Median percentage change

\begin{tabular}{|c|c|c|c|c|c|c|}
\hline & \multicolumn{3}{|l|}{$\mathrm{D}_{1}$ agonist } & \multicolumn{3}{|l|}{ DA } \\
\hline & Amplitude & Duration & Area & Amplitude & Duration & Area \\
\hline Control & $27(12-75)^{a}$ & $17(0-38)$ & $66(11-119)$ & $64(23-100)$ & $14(6-44)$ & $115(58-181)$ \\
\hline Mutant & $0(-9$ to 9$)$ & $0(0-15)$ & $3(-3 \text { to } 19)^{b}$ & $0(-19 \text { to } 26)^{b}$ & $2(-12 \text { to } 6)^{b}$ & $0(-19 \text { to } 26)^{b}$ \\
\hline
\end{tabular}

${ }^{a}$ Median percentage change. Interquartile range in parentheses. Numbers are the same as in A.

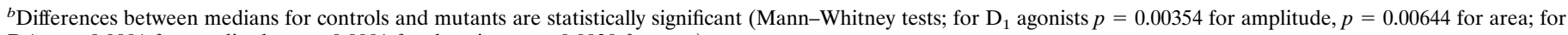
DA $p<0.0001$ for amplitude, $p<0.0001$ for duration, $p=0.0030$ for area).

increases in response amplitude, half-amplitude duration, and area were statistically significant compared with baseline conditions $(t=3.01, \mathrm{df}=12, p=0.0109$ for amplitude; $t=6.48, \mathrm{df}=$ $12, p=0.0074$ for half-amplitude duration; $t=3.43, \mathrm{df}=12, p=$ 0.005 for area) (Table $2 \mathrm{~A}$ ). In mutants, changes induced by $\mathrm{D}_{1}$ agonists from baseline conditions in amplitude, half-amplitude duration, and area were not statistically significant (Table 2A). Comparisons between controls and mutants in both mean and median changes in response parameters were statistically significant (Table 2A,B). For all mean comparisons and for median comparisons of amplitude and area, the effects of $\mathrm{D}_{1}$ agonists were significantly attenuated for mutants relative to controls.

To further examine changes in the population of cells, distributions of percentage change in response area were constructed from pooled data from experiments assessing $\mathrm{D}_{1}$ agonist effects on iontophoretic responses and on DPSPs mediated by activation of NMDA receptors (Fig. 6). In controls, most responses (84\%, 11/13) were increased in area in the presence of SKF 38393 or A-77636, and $68 \%(9 / 13)$ of the cells displayed increases $>20 \%$. In contrast, the distribution of percentage change in response area in mutant cells appeared to cluster around zero. In mutants, $48 \%$ $(9 / 19)$ of the cells displayed changes in area between $\pm 10 \%$, whereas $31 \%$ (6/19) displayed decreases in area $>10 \%$. Only $21 \%$ $(4 / 19)$ of the cells displayed increases $>20 \%$.

The effects of SKF 38393 also were assessed on DPSPs evoked in standard ACSF (Table 3). In this bath solution, it has been demonstrated that the DPSP is mediated primarily by activation of non-NMDA receptors, because it can be blocked almost com- 
CONTROL

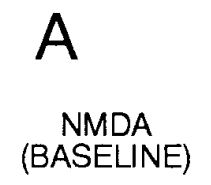

NMDA
+
SKF 38393
$(20 \mu \mathrm{M}, 10 \mathrm{~min})$

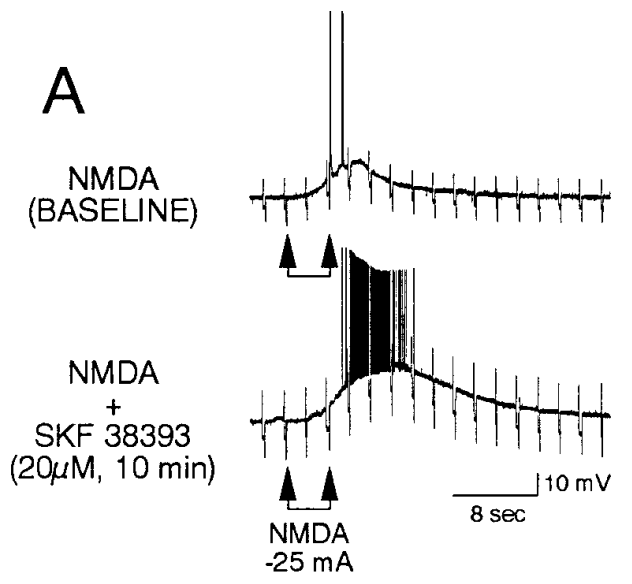

MUTANT

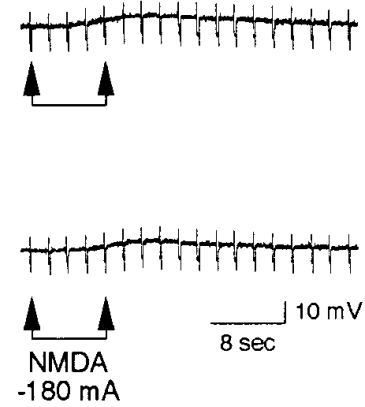

Figure 4. Effects of $\mathrm{D}_{1}$ agonists on responses induced by iontophoretic application of NMDA. A, Effects of SKF 38393. Left column shows a cell from a control mouse. Top trace is baseline response to NMDA alone. Bottom trace shows the potentiation of the response in the presence of bath application of SKF 38393. Right column shows a cell from a mutant. Top trace shows a small depolarizing response to NMDA alone. Bottom trace shows that this response was not altered in the presence of SKF 38393. In this and other figures, iontophoretic current is applied between the arrows, and the numbers next to or below the arrows are the iontophoretic current polarity and intensity. Downward deflections are voltage responses to hyperpolarizing current pulses. Calibrations refer to each column. $B$, Effects of A-77636. Left column shows a cell from a control mouse. Top trace is baseline response to NMDA alone. Bottom trace shows the potentiation of the response in the presence of bath application of A-77636. Action potentials have been truncated for illustrative purposes. Right column shows a cell from a mutant. Top trace shows a depolarizing response to NMDA alone. Bottom trace shows that this response was not altered in the presence of A-77636. Calibration refers to all traces in $B$.
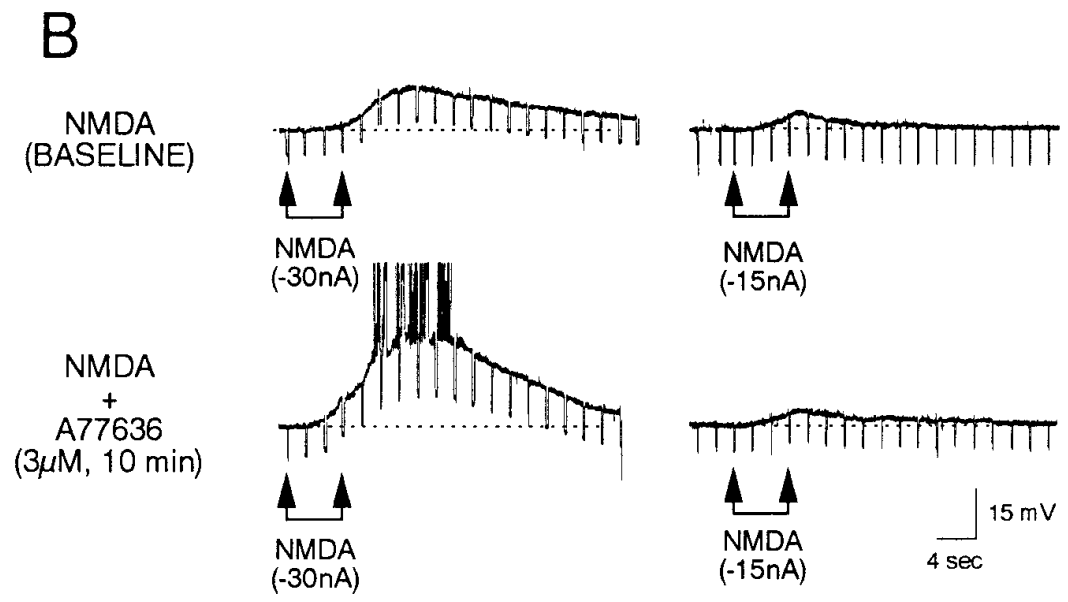

pletely by application of CNQX (Nisenbaum et al., 1993; Levine et al., 1996). In standard ACSF, SKF 38393 did not have consistent or statistically significant effects on the evoked DPSP obtained from cells from mutants or controls (Table 3). Both increases $[40 \%(2 / 5)$ in controls, 64\% (7/11) in mutants] and decreases [60\% (3/5) in controls, $36 \%(4 / 11)$ in mutants] occurred, and there was little net percentage change (Table 3 ).

\section{Effects of $D A$}

The effects of DA also were evaluated in experiments using iontophoretic application of NMDA and experiments in which DPSPs were mediated by activation of NMDA receptors.

In control mice, DA markedly potentiated responses induced by iontophoretic application of NMDA (Fig. 7) and increased the size of DPSPs mediated by activation of NMDA receptors (Fig. 8). In contrast in mutants, DA did not consistently alter responses induced by iontophoretic application of NMDA (Fig. 7) or DPSPs mediated by NMDA receptor activation (Fig. 8).

Again, data were pooled for quantitative analysis, because there were no differences in percentage changes in response parameters between both methods of evoking NMDA-induced responses. In the presence of DA in controls, amplitudes, durations, and areas of responses significantly increased compared with control conditions $(t=4.32$, df $=22, p=0.0003$ for amplitude; $t=3.66$, df $=$
$22, p=0.0014$ for duration; $t=2.98, \mathrm{df}=22, p=0.0069$ for area). DA did not significantly alter mean or median amplitudes, durations, or areas in mutants compared with control conditions (Table 2A,B). Comparisons between controls and mutants in both mean and median changes in response parameters were statistically significant. The differences between controls and mutants in amplitude, half-amplitude duration, and area were all statistically significantly (Table 2A,B). Examination of the distributions of changes in response area revealed that although responses evoked in control animals were consistently enhanced by DA $(96 \%$, $22 / 23$ ), responses evoked in mutants were more variably affected (Fig. 6). In mutants, DA decreased 54\% (10/19) of the responses imately $10 \%(2 / 19)$ of the responses in mutants displayed large increases in the presence of DA ( $>150 \%$ increase in area).

In standard ACSF in cells from controls, DA produced statistically significant decreases in mean response amplitude, duration, and area $(t=4.29, \mathrm{df}=11, p=0.0013$ for amplitude; $t=2.26$, $\mathrm{df}=11, p=0.0453$ for half-amplitude duration; $t=3.16, \mathrm{df}=11$, $p=0.0091$ for area) (Table 3). Most $(75 \%, 8 / 12)$ of the cells displayed decreases in area by $>20 \%$, one cell decreased between 0 and $20 \%$, and the remaining cells (3/12) displayed increases in area between 0 and $20 \%$. In mutants, the alterations in responses and enhanced $\sim 25 \%(5 / 19)$ of the responses by $>20 \%$. Approx- 


\section{$\mathrm{Mg}^{2+}$ Free ACSF/CNQX $(5 \mu \mathrm{M})$}
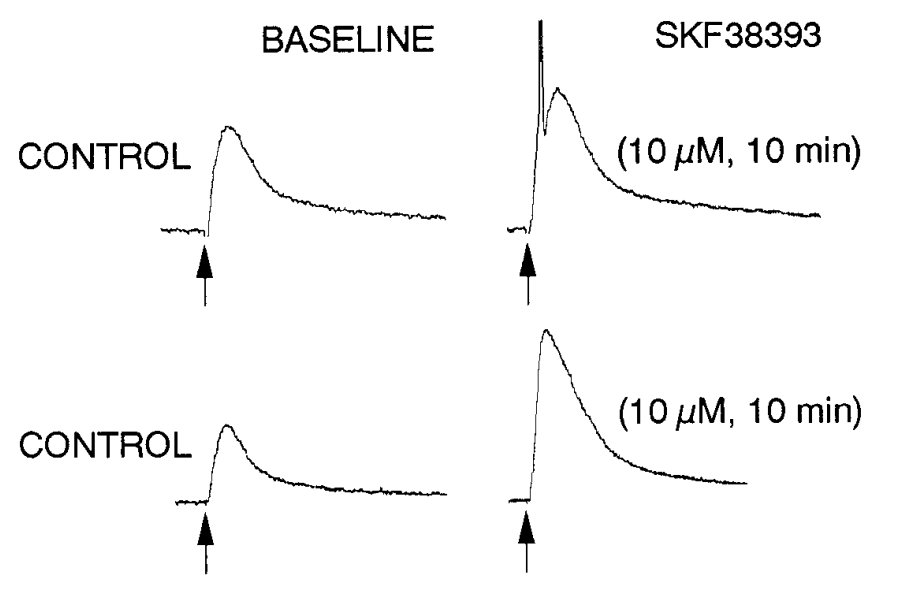

MUTANT

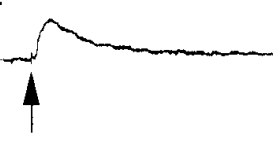

$(10 \mu \mathrm{M}, 10 \mathrm{~min})$

$(20 \mu \mathrm{M}, 10 \mathrm{~min})$

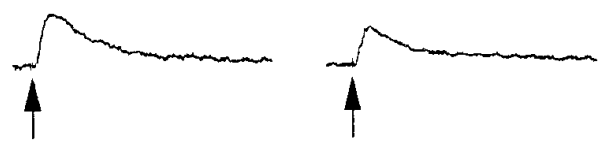

MUTANT

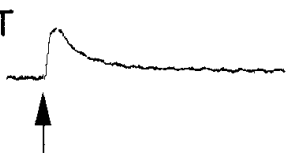

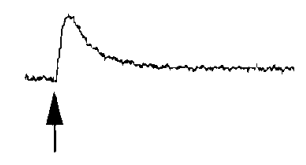

Figure 5. Examples of effects of SKF 38393 on DPSPs. All cells were bathed in $\mathrm{Mg}^{2+}$-free ACSF containing CNQX $(5 \mu \mathrm{M})$ to evoke DPSPs mediated by activation of NMDA receptors. Top two sets of traces show DPSPs obtained from two cells from controls. Left traces are baseline responses. Right traces show potentiation of responses in the presence of SKF 38393. Bottom two sets of traces are from two cells obtained from mutants. Left traces are baseline responses. Middle traces show minimal potentiation at $10 \mu \mathrm{M}$ SKF 38393. Right traces show that minimal potentiation also occurred when the concentration of SKF 38393 was increased to $20 \mu \mathrm{M}$. All traces are averages of four to six responses. Local electrical stimulation is applied at the arrow. Calibration refers to all traces. induced by DA were more variable than those produced in controls. The mean changes in response amplitude, duration, and area were not statistically significant compared with baseline conditions for mutants. Although mutants and controls did not differ significantly on any of the measures in standard ACSF, only $30 \%(3 / 10)$ of the mutant cells displayed decreases in response area $>20 \%$, and $40 \%(4 / 10)$ displayed decreases between 0 and $20 \%$. The remainder (3/10) showed increases of $>20 \%$.

\section{Neuronal identification}

A total of 58 neurons were labeled ( 27 from mutants and 31 from controls). All but one cell had the appearance of medium-size spiny neurons. There were no marked qualitative or quantitative differences between cells from mutants and controls (Fig. 9, Table 4). Average somatic cross-sectional area and short- and long-axis diameters were similar (Table 4). There were no significant differences in dendritic length or in the estimate for dendritic spine

Table 3. Modulation of DPSPs in standard ACSF

A. Mean percentage change

\begin{tabular}{|c|c|c|c|c|c|c|}
\hline & \multicolumn{3}{|l|}{$\underline{\mathrm{D}_{1} \text { agonist }}$} & \multicolumn{3}{|l|}{ DA } \\
\hline & Amplitude & Duration & Area & Amplitude & Duration & Area \\
\hline Control & $5 \pm 9(n=6)^{a}$ & $1 \pm 10$ & $8 \pm 17$ & $-23 \pm 6(n=12)$ & $-13 \pm 6$ & $-31 \pm 8$ \\
\hline Mutant & $6 \pm 5(n=11)$ & $3 \pm 6$ & $11 \pm 9$ & $-12 \pm 12(n=12)$ & $14 \pm 14$ & $-8 \pm 11$ \\
\hline
\end{tabular}

${ }^{a}$ Mean \pm SE. Number for each group is in parentheses. Numbers are percentage changes with respect to baseline.

B. Median percentage change

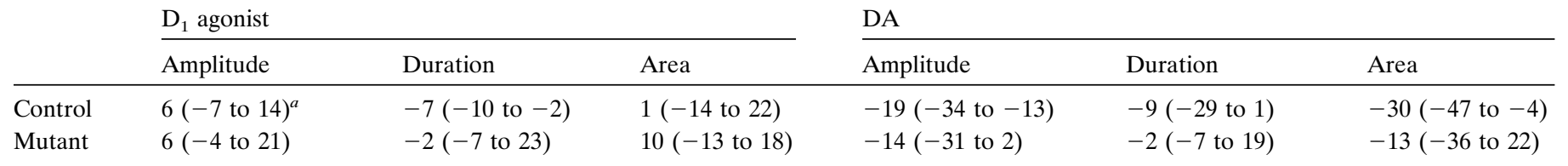

${ }^{a}$ Median percentage change. Interquartile range in parentheses. $n$ is the same as in A. 

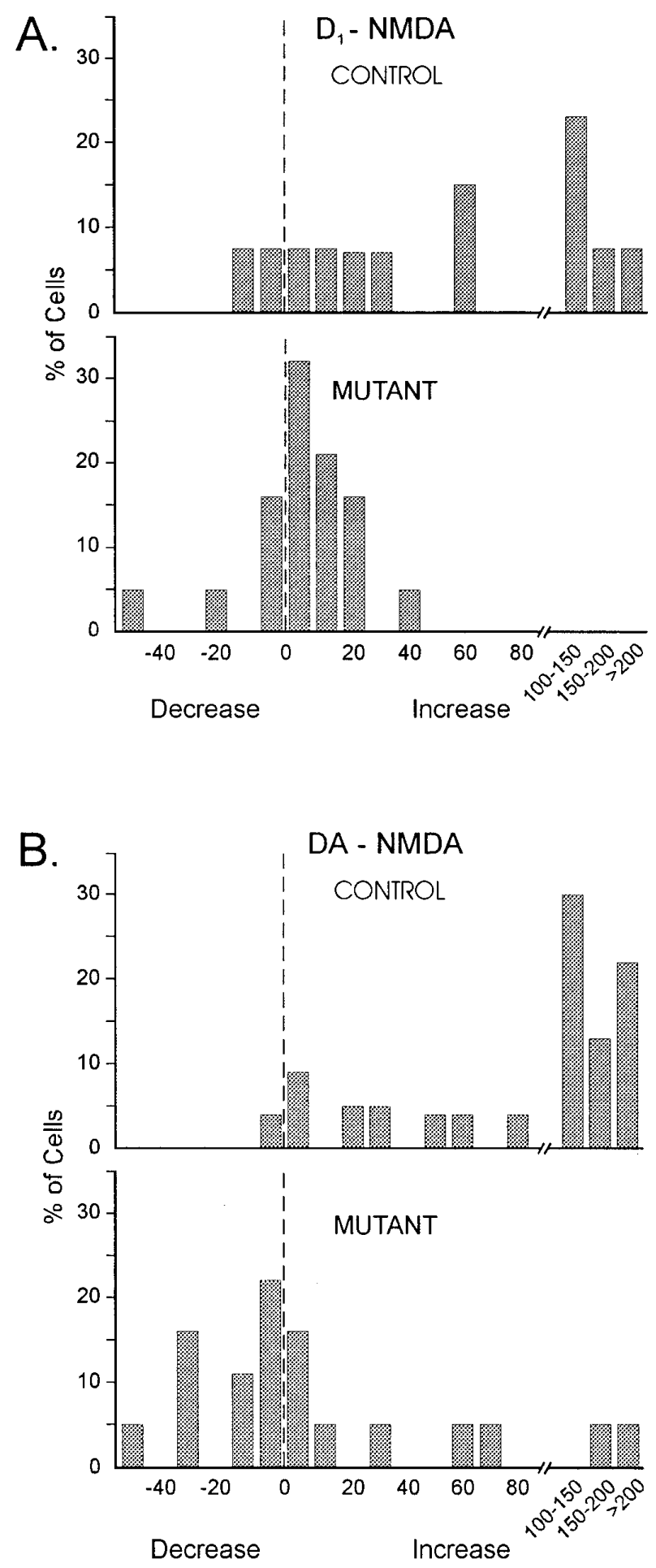

Figure 6. Distributions of percentage change in response area. A, Top two graphs show distributions of changes in response area for all cells from controls and mutants that were exposed to $\mathrm{D}_{1}$ agonists under conditions activating NMDA receptors. Response area of almost all cells in controls increased after exposure to $D_{1}$ agonists. In contrast, in mutants, changes distributed around zero. $B$, Bottom two graphs show distributions of changes in response area for all cells from controls and mutants that were exposed to DA. Response area of almost all cells in controls increased after exposure to DA. In contrast, in mutants, there was a wide distribution with a large proportion of cells decreasing in response area. For all graphs, vertical axes are the percentages of cells falling into each category. Horizontal axes are the percentage changes in response area. Note that both increases and decreases in response area are shown. density (Table 4). In both groups, a small sample of neurons were dye-coupled $[15 \%$ (4/27 recovered cells in mutants) and $13 \%$ $(4 / 31)$ in controls].

\section{DISCUSSION}

The present experiments had two purposes. The first was to use the $\mathrm{D}_{1 \mathrm{~A}}$ DA receptor-deficient mutant to examine the hypothesis that DA-induced enhancement of responses mediated by activation of neostriatal NMDA receptors is attributable to activation of $\mathrm{D}_{1}$ DA receptors. The second was to assess basic electrophysiological and morphological properties of neostriatal neurons in mice lacking $\mathrm{D}_{1 \mathrm{~A}}$ DA receptors.

\section{DA modulation of NMDA responses}

Based on our previous findings (Cepeda et al., 1993; Levine et al., 1996), we would predict that either DA would not enhance NMDA-mediated responses or that the enhancement would be severely attenuated in the mutant. The results provide evidence to support this hypothesis. When responses were mediated by activation of NMDA receptors in mutants, DA had minimal effects. Furthermore, agonist activation of $\mathrm{D}_{1}$ receptors also had little net effect on responses mediated by NMDA receptors. These outcomes suggested that there was minimal compensation for this function of $\mathrm{D}_{1 \mathrm{~A}}$ receptors by $\mathrm{D}_{1 \mathrm{~B}} \mathrm{DA}$ or serotonin receptors in the mutant. However, it should be pointed out that a small population of cells in the mutant displayed large increases in NMDA receptor-mediated response to DA or $\mathrm{D}_{1}$ agonists. It is possible that this population expresses $\mathrm{D}_{1 \mathrm{~B}}$ receptors (CarterRussell et al., 1995).

Previously, we have demonstrated that $\mathrm{DA}$ and $\mathrm{D}_{1}$ agonists enhanced responses mediated by activation of NMDA receptors in rat neostriatum, cat caudate nucleus, human caudate nucleus, and human neocortex (Cepeda et al., 1992b, 1993, 1994). The present studies demonstrated that similar enhancement occurs in the control mouse, indicating that DA/NMDA receptor interactions in the neostriatum are distributed widely across species. In contrast, there is diversity in how DA modulation of EAA transmission is expressed in different neural areas. DA enhances nonNMDA receptor-mediated responses via $D_{1}$ receptors and the cAMP/PKA transduction cascade in cultured chick spinal cord motoneurons (Smith et al., 1995), in goldfish Mauthner cells (Pereda et al., 1992, 1994), and in the retina (Knapp et al., 1990). In the hippocampus, DA, via $\mathrm{D}_{1}$ receptor activation, induces a long-lasting synaptic potentiation (Huang and Kandel, 1995) involving both NMDA and non-NMDA receptors (Frey et al., 1993; Huang and Kandel, 1995). DA reduces excitatory synaptic transmission in nucleus accumbens by activating presynaptic $\mathrm{D}_{1} \mathrm{DA}$ receptors (Higashi et al., 1989; Pennartz et al., 1992; Nicola et al., 1996). In the neocortex, DA and $D_{1}$ activation decreases both

Table 4. Measurements from biocytin-filled cells

\begin{tabular}{lcc} 
& Control & Mutant \\
\hline Somatic cross-section area $\left(\mu \mathrm{m}^{2}\right)$ & $145 \pm 10^{a}$ & $132 \pm 12$ \\
Somatic long axis diameter $(\mu \mathrm{m})$ & $16.9 \pm 0.7$ & $15.9 \pm 0.8$ \\
Somatic short axis diameter $(\mu \mathrm{m})$ & $13.0 \pm 0.6$ & $12.9 \pm 0.8$ \\
Average dendrite length $(\mu \mathrm{m})^{b}$ & $150 \pm 5.5$ & $143 \pm 4.6$ \\
Spine density $^{c}$ & $1.21 \pm 0.2$ & $1.24 \pm 0.3$ \\
\hline
\end{tabular}

${ }^{a}$ Mean $\pm \mathrm{SE} ; n=31$ for controls and $n=27$ for mutants.

${ }^{b}$ Average of the length of three dendrites for each cell.

${ }^{c}$ Average of the rating scores for each cell. See text for explanation of ratings for spine density. 


\section{CONTROL}

\section{NMDA \\ (BASELINE)}

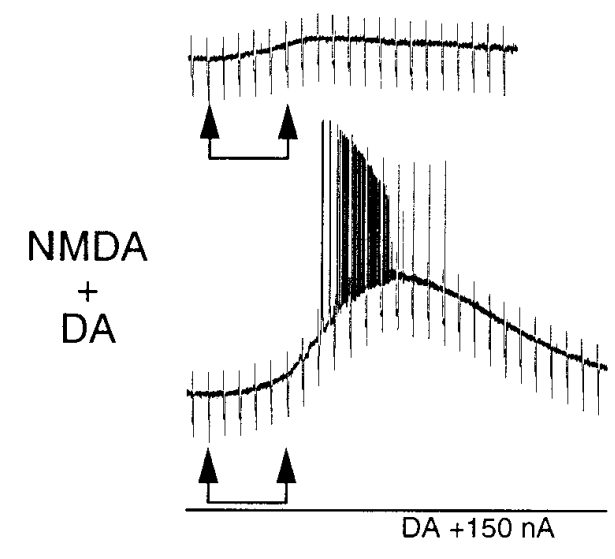

NMDA

(WASH)

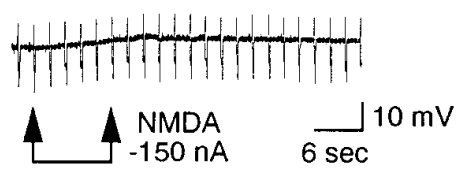

CONTROL

MUTANT
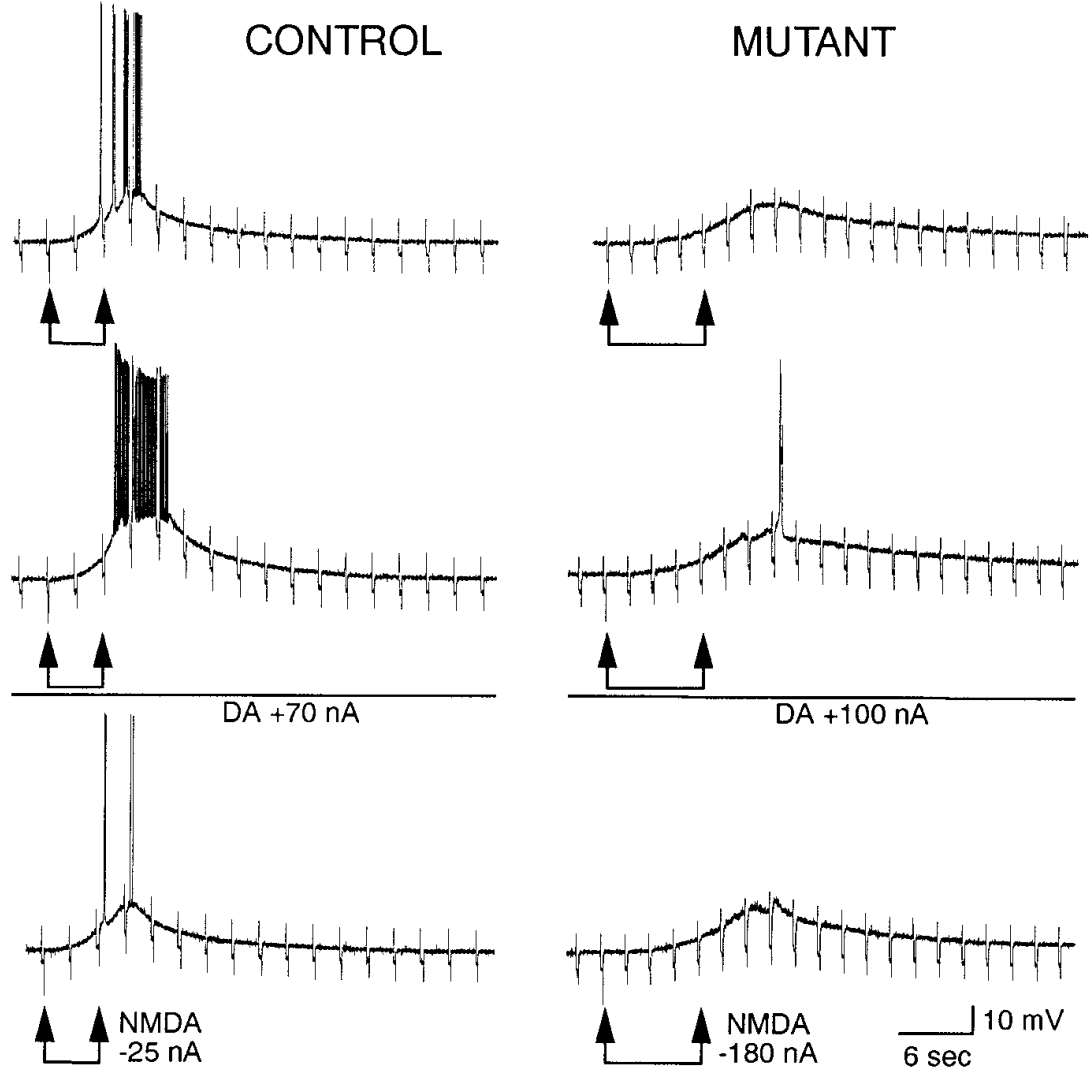
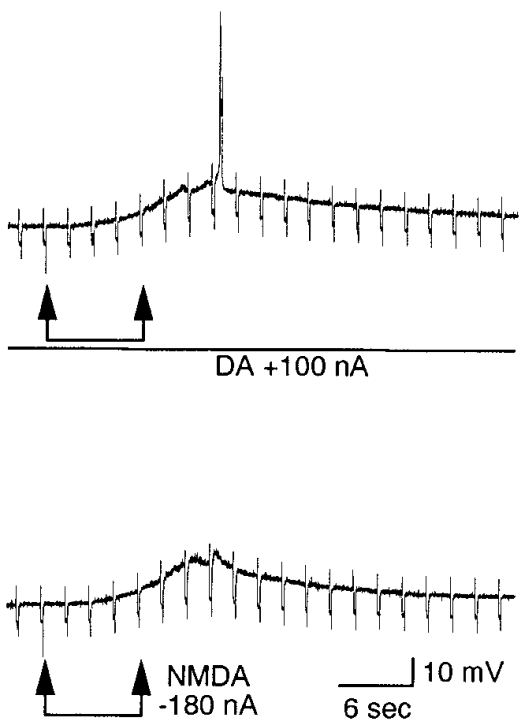

Figure 7. Example of effects of DA on responses induced by iontophoretic application of NMDA. Left and middle columns show cells from controls. Top traces are baseline responses to NMDA alone. Middle traces show the potentiation of the responses in the presence of iontophoretic application of DA. In all columns, DA was applied for 1 min before and during NMDA. Bottom traces show wash 4 min after DA application ceased. Right column shows a cell from a mutant. Top trace shows a depolarizing response to NMDA alone. Middle trace shows that this response was minimally altered in the presence of DA. Bottom trace shows wash 4 min after application of DA. Calibration at left refers to left column. Calibration at right refers to middle and right columns.

non-NMDA and NMDA-mediated synaptic transmission (LawTho et al., 1994). It would appear then, that the actions of DA are expressed differently depending on the area and, possibly, the type of neuron studied.

Synaptic responses evoked in vivo by cortical stimulation and synaptic responses evoked by local stimulation in vitro in neostriatal slices bathed in standard ACSF have been shown to be mediated primarily by activation of non-NMDA glutamate receptors (Herrling, 1985; Cherubini et al., 1988; Nisenbaum et al., 1993;
Levine et al., 1996). DA typically decreases the size of these responses in a concentration-dependent manner (Herrling and Hull, 1980; Mercuri et al., 1985; Levine et al., 1996). The present experiments demonstrated that this decrease occurred in the control mouse. However, the mutant showed considerable variability in this action of DA. We have demonstrated that the attenuation by DA of non-NMDA receptor-mediated responses may involve $\mathrm{D}_{2}$ receptors, because it is mimicked by quinpirole, a $\mathrm{D}_{2}$ receptor agonist, and blocked by domperidone, $\mathrm{D}_{2}$ receptor-

\section{$\mathrm{Mg}^{2+}$ Free ACSF/CNQX $(5 \mu \mathrm{M})$}

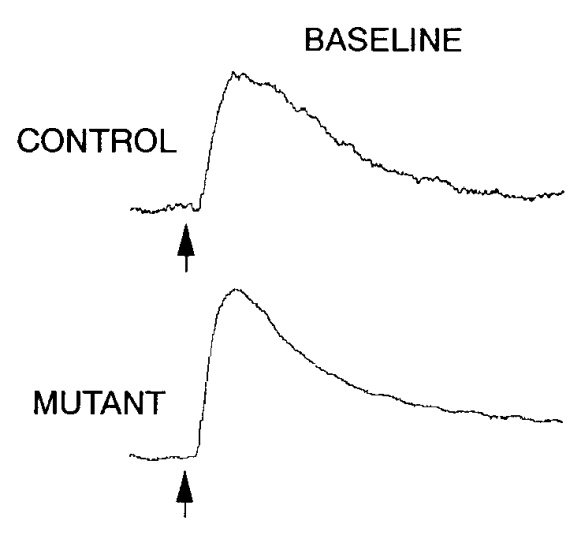

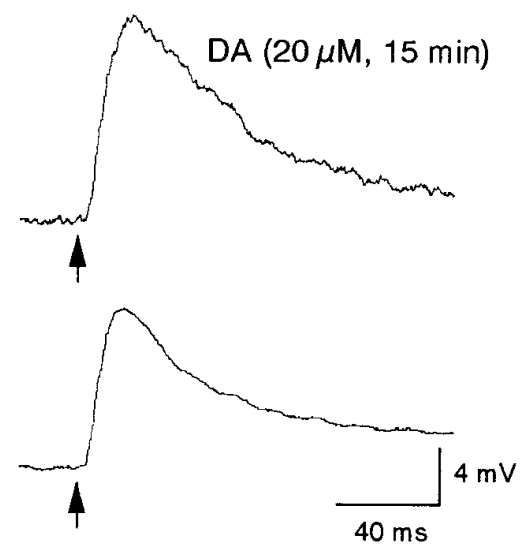

Figure 8. Examples of effects of DA on DPSPs. All cells were bathed in $\mathrm{Mg}^{2+}$-free ACSF containing CNQX $(5 \mu \mathrm{M})$ to evoke DPSPs mediated by activation of NMDA receptors. Top trace shows DPSPs obtained from a control cell. Left trace is baseline response. Right trace shows potentiation of the response in the presence of DA. Bottom traces are from a mutant cell. Left trace is baseline. Right trace shows that potentiation did not occur in the presence of DA. All traces are averages of four to six responses. Local electrical stimulation is applied at the arrow. Calibration refers to all traces. 

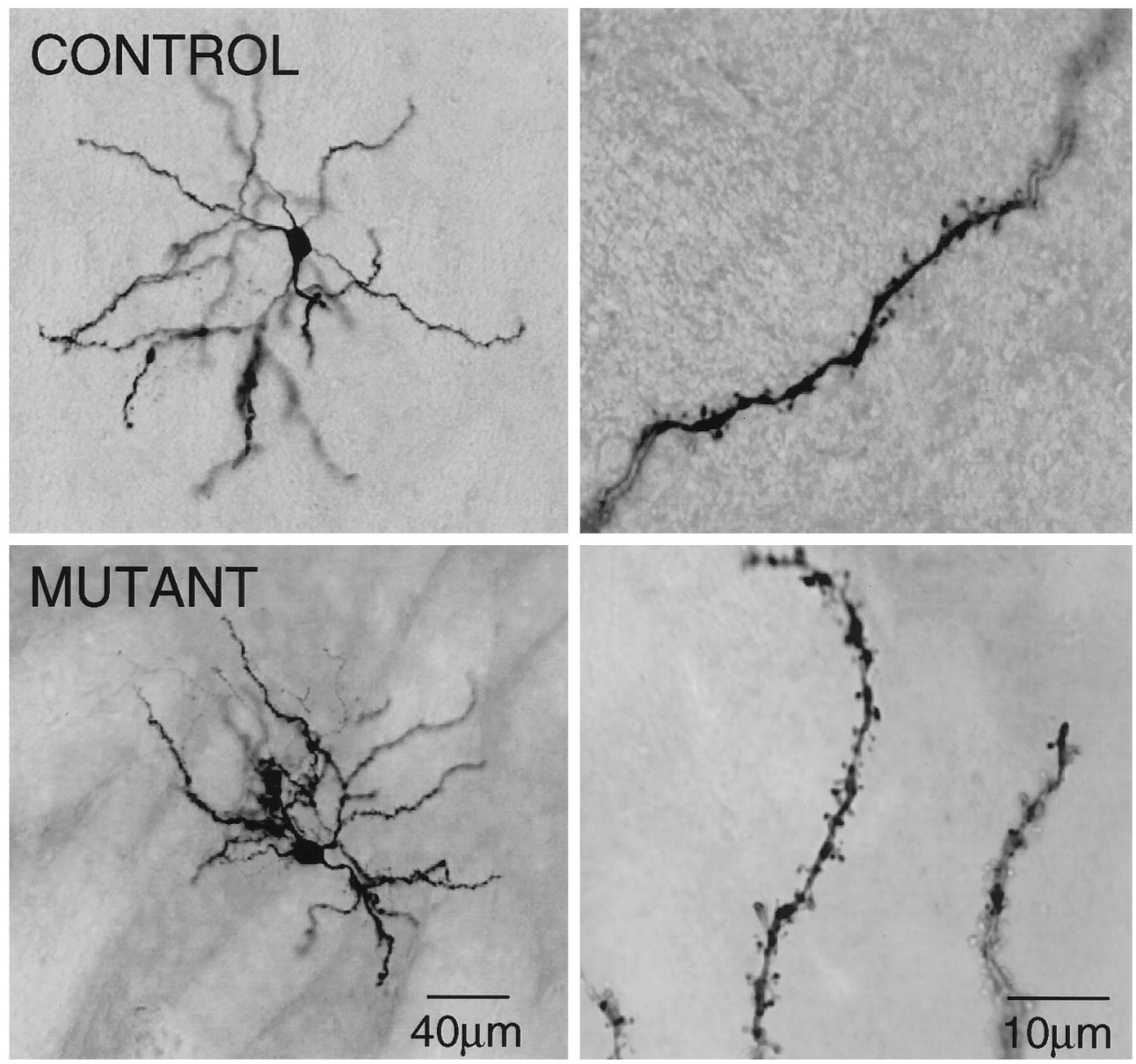

Figure 9. Photomicrographs of biocytinfilled cells. The top shows a control cell at two magnifications. The bottom shows a cell from a mutant at two magnifications. The dendrites of the cells from both the control and the mutant mice were covered with spines.

specific antagonist (Levine et al., 1996). It is presently unclear why responses that may be mediated by $\mathrm{D}_{2}$ receptors are altered potentially in the mutant. Although we did not test the effects of $\mathrm{D}_{2}$ agonists in the present studies, it is conceivable that coupling of $\mathrm{D}_{1}$ and $\mathrm{D}_{2}$ receptors is necessary for DA to produce robust and consistent attenuation of non-NMDA receptor-mediated responses (Hu and White, 1994). Additional evidence has been obtained for electrophysiological alterations in $\mathrm{D}_{2}$ receptor function in nucleus accumbens in $\mathrm{D}_{1 \mathrm{~A}}$ mutants (Xu et al., 1994b). Clearly, more studies must be performed to examine and clarify this issue.

The present experiments support the findings that specific combinations of receptor subtype interactions lead to predictable responses. Based on our previous work (Cepeda et al., 1992b, 1993; Levine et al., 1996), activation of two combinations of EAA and DA receptor subtypes have very predictable outcomes. DA or the $\mathrm{D}_{1}$ agonist potentiate NMDA-mediated responses, whereas DA or the $\mathrm{D}_{2}$ agonist attenuate responses mediated by non-NMDA receptor activation. Other combinations do not lead to predictable outcomes. The present study examined the effects of DA or $\mathrm{D}_{1}$ receptor agonists on both NMDA and non-NMDA receptor-induced responses. $\mathrm{D}_{1}$ receptor activation had variable effects on responses induced by activation of non-NMDA receptors. In contrast, NMDA receptor-induced responses were potentiated consistently by DA or $\mathrm{D}_{1}$ receptor activation. A number of possibilities could account for highly predictable outcomes when NMDA and DA or $\mathrm{D}_{1}$ receptors are activated. A spatial or mechanistic coupling of these specific receptor subtypes may occur. NMDA and $\mathrm{D}_{1}$ receptor subtypes may be located in close proximity on the same spine, dendrite, or cell (Yung et al., 1995). Alternatively, $\mathrm{D}_{1}$ and NMDA receptors use the same transduction systems. Increasing cAMP enhances responses mediated by activation of NMDA receptors (Colwell and Levine, 1995), and $D_{1}$ DA receptor activation increases cAMP (Stoof and Kebabian, 1981).

\section{Basic electrophysiology and morphology}

The present study showed that some basic electrophysiological and morphological properties of medium-size spiny neurons were not altered in the mutant. Except for the larger input resistance of cells in mutants bathed in $\mathrm{Mg}^{2+}$-free ACSF with CNQX, resting membrane potential, action potential parameters, input resistance, and basic measures of excitability were similar. Input resistance typically is attributed to $\mathrm{K}^{+}$conductances. Without additional study of isolated conductances, it would be premature to speculate on the alterations underlying this increase in input resistance in the mutant cells bathed in $\mathrm{Mg}^{2+}$-free ACSF with CNQX. Few differences in the amplitudes, half-amplitude durations, and areas of responses in both standard ACSF and $\mathrm{Mg}^{2+}$. free ACSF containing CNQX were noted. There was a statistically significant increase in DPSP area in standard ACSF in mutants compared with controls. Because this response is primarily mediated by activation of non-NMDA receptors, it is possible that this receptor subtype has been altered in the mutant. Additional experiments will be necessary to examine this issue in more detail. No major differences in morphological parameters of the identified neurons were found. Most recordings were from medium-size 
spiny cells (Kawaguchi et al., 1989; Cepeda et al., 1992a, 1994); only one labeled cell was not a medium-size spiny neuron. However, the present analysis did not include detailed quantification. Subtle differences between medium-size neostriatal cells in mutants and controls may have been overlooked. We did not attempt to double label cells for neurotransmitters or receptors, or to determine their location with respect to patch or matrix compartments (Xu et al., 1994a).

\section{Morphology, behavior, and electrophysiology in mutants}

The present experiments provide additional molecular evidence validating the absence of $\mathrm{D}_{1 \mathrm{~A}}$ receptors in the mutant. Previously, in situ hybridization studies demonstrated that the mutant lacks message for the $\mathrm{D}_{1 \mathrm{~A}}$ receptor in the neostriatum (Drago et al., 1994). The findings obtained from the present reverse transcriptase experiments validate this outcome. The immunohistochemical demonstration that the neostriatum lacks $\mathrm{D}_{1 \mathrm{~A}}$ protein, however, is new and provides additional evidence for lack of receptor protein in the mutant. Previous studies of $\mathrm{D}_{1 \mathrm{~A}} \mathrm{DA}$ receptor mutant mice have demonstrated a number of other morphological, electrophysiological, and behavioral alterations. Expression of dynorphin and substance $\mathrm{P}$ in the neostriatum is reduced (Drago et al., 1994; Xu et al., 1994a). Mutant mice are hyperactive, display decreased rearing, and do not respond behaviorally to $\mathrm{D}_{1}$ receptor agonists (Drago et al., 1994; Xu et al., 1994a,b). Cocaine, which produces hyperactivity in control mice, does not increase activity in mutants (Xu et al., 1994b; Miner et al., 1995). In extracellular electrophysiological studies, inhibitory effects of cocaine on nucleus accumbens neurons are reduced, and the inhibitory effects of $\mathrm{D}_{1}$ and $\mathrm{D}_{2}$ agonists are almost abolished (Xu et al., 1994b), suggesting that enabling interactions between $\mathrm{D}_{1}$ and $\mathrm{D}_{2}$ receptors are altered substantially ( $\mathrm{Hu}$ and White, 1994).

Our results extend these findings and provide the first intracellular electrophysiological analysis of neostriatal neurons in this mutant strain. Neostriatal cells in mutants do not appear to be different from those in control mice. Neostriatal spiny neurons have similar gross morphological appearances in terms of somata, dendritic extent, and estimates of spine density. It is not surprising that these basic parameters are unaffected, because the mice survive and, unless challenged, appear similar to their littermates. When these animals are exposed to treatments that activate $D_{1 \mathrm{~A}}$ receptors, then deficits appear.

\section{Factors contributing to NMDA responses and DA modulation}

The primary focus of this study was to determine whether DAinduced modulation was altered in the mutant. The present experiments were not designed to isolate the factors contributing to DA modulation of NMDA receptor-mediated responses in control and mutant mice. To provide validation, two complementary methods were used to evoke responses mediated by activation of NMDA receptors. In the first, NMDA was applied iontophoretically. This approach has the advantage of direct agonist application. However, surrounding neurons also are activated and may contribute to the response. We have demonstrated that DA and $\mathrm{D}_{1}$ agonists potentiate responses induced by NMDA receptor activation when activity of surrounding neurons was blocked by tetrodotoxin (Cepeda et al., 1995). Thus, it is unlikely that the surrounding cells added significantly to the effects of NMDA. The second approach used synaptic activation in $\mathrm{Mg}^{2+}$-free ACSF containing CNQX to evoke NMDA receptor activation. A disad- vantage of this approach is that synaptic stimulation, although activating glutamatergic afferents, also activates local circuitry. We did not attempt to rule out contributions of GABA receptor activation or acetylcholine receptor activation in the present study. Previously, we have demonstrated that blockade of $\mathrm{GABA}_{\mathrm{A}}$ receptors has little influence on the modulatory actions of DA on EAA agonist-evoked responses (Levine et al., 1996). In addition, the cholinergic component appears to be minor when responses are evoked primarily by stimulation of afferents as described in the present study (Misgeld et al., 1980; Walsh et al., 1989; Cromwell et al., 1994).

\section{Conclusions}

The present studies provide evidence that the $\mathrm{D}_{1 \mathrm{~A}}$ receptor is necessary for DA to produce enhancement of responses mediated by activation of NMDA receptors. Furthermore, the findings support the idea that the effects of DA on responses mediated by non-NMDA receptors may require coupling or interactions between $D_{1}$ and $D_{2}$ receptor subtypes. Finally, these studies demonstrate that mutant mice provide a powerful tool for exploring ideas and testing hypotheses concerning the functional roles of DA receptor subtypes.

\section{REFERENCES}

Accili D, Fishbourne CS, Drago J, Steiner H, Lachowicz JE, Gerfen CR, Sibley DR, Westphal H, Fuchs S (1996) A targeted mutation of the $\mathrm{D}_{3}$ dopamine receptor gene is associated with hyperactivity in mice. Proc Natl Acad Sci USA 93:1945-1949.

Acquas E, Day JC, Fibiger HC (1994) The potent and selective dopamine D1 receptor agonist A-77636 increases cortical and hippocampal acetylcholine release in the rat. Eur J Pharmacol 260:85-87.

Altemus KL, Levine MS (1996) Potassium channel blockade does not alter the modulatory effects of dopamine in neostriatal slices. Brain Res 718:212-216.

Ariano MA, Sibley DR (1994) Dopamine receptor distribution in the rat CNS: elucidation using anti-peptide antisera directed against $\mathrm{D}_{1 \mathrm{~A}}$ and $\mathrm{D}_{3}$ subtypes. Brain Res 649:95-110.

Balk J-H, Picetti R, Salardi A, Thirlet G, Dierich A, Depaulls A, LeMeur M, Borrelli E (1995) Parkinsonian-like locomotor impairments in mice lacking dopamine $\mathrm{D}_{2}$ receptors. Nature 377:424-428.

Bouyer JJ, Park DH, Joh TH, Pickel VM (1984) Chemical and structural analysis of the relation between cortical inputs and tyrosine hydroxylase-containing terminals in rat neostriatum. Brain Res 302:267-275.

Carter-Russell HR, Song W-J, Surmeier DJ (1995) Coordinated expression of dopamine receptors (D1-D5) in single neostriatal neurons. Soc Neurosci Abstr 21:1425.

Cepeda C, Peacock W, Levine MS, Buchwald NA (1991a) Iontophoretic application of NMDA produces different types of excitatory responses in developing human cortical and caudate neurons. Neurosci Lett 126:167-171.

Cepeda C, Walsh JP, Buchwald NA, Levine MS (1991b) Neurophysiological maturation of cat caudate neurons: evidence from in vitro studies. Synapse 7:278-290.

Cepeda C, Lee N, Radisavljevic Z, Buchwald NA, Levine MS (1992a) Age-induced changes in electrophysiological responses of neostriatal neurons recorded in vitro. Neuroscience 51:411-423.

Cepeda C, Radisavljevic Z, Peacock W, Levine MS, Buchwald NA (1992b) Differential modulation by dopamine of responses evoked by excitatory amino acids in human cortex. Synapse 11:330-341.

Cepeda C, Buchwald NA, Levine MS (1993) Neuromodulatory actions of dopamine in the neostriatum are dependent upon the excitatory amino acid receptor subtypes activated. Proc Natl Acad Sci USA 90:9576-9580.

Cepeda C, Walsh JP, Peacock W, Buchwald NA, Levine MS (1994) Neurophysiological, pharmacological and morphological properties of human caudate neurons recorded in vitro. Neuroscience 59:89-103.

Cepeda C, Yu Q, Colwell CS, Buchwald NA, Levine MS (1995) NMDAinduced excitotoxicity in visually identified neostriatal neurons in slices. Modulation by dopamine. Soc Neurosci Abstr 21:912. 
Cepeda C, Li Z, Levine MS (1996) Aging reduces neostriatal responsiveness to $N$-methyl-D-aspartate and dopamine; an in vitro electrophysiological study. Neuroscience 73:733-750.

Cherubini E, Herrling PL, Lanfumey L, Stanzione PJ (1988) Excitatory amino acids in synaptic excitation of rat striatal neurones in vitro. J Physiol (Lond) 400:677-690.

Colwell CS, Levine MS (1995) Excitatory synaptic transmission in neostriatal neurons: regulation by cyclic AMP-dependent mechanisms. J Neurosci 15:1704-1713.

Cromwell HC, Buchwald NA, Levine MS (1994) Decortication alters locally evoked synaptic responses in the rat neostriatal slice. Soc Neurosci Abstr 20:563.

Drago J, Gerfen CR, Lachowicz JE, Steiner H, Hollon TR, Love PE, Ooi GT, Grinberg A, Lee EJ, Huang SP, Bartlett PF, Jose PA, Sibley DR, Westphal H (1994) Altered striatal function in a mutant mouse lacking $\mathrm{D}_{1 \mathrm{~A}}$ dopamine receptors. Proc Natl Acad Sci USA 91:12564-12568.

Freund TF, Powell J, Smith AD (1984) Tyrosine hydroxylase immunoreactive boutons in synaptic contact with identified striatonigral neurons with particular reference to dendritic spines. Neuroscience 13:1189-1215.

Frey U, Huang Y-Y, Kandel ER (1993) Effects of cAMP simulate a late stage of LTP in hippocampal CA1 neurons. Science 260:1661-1664.

Herrling PL (1985) Pharmacology of the corticocaudate excitatory postsynaptic potentials in the cat: evidence for its mediation by quisqualate- or kainate-receptors. Neuroscience 14:417-426.

Herrling PL, Hull CD (1980) Iontophoretically applied dopamine depolarizes and hyperpolarizes the membrane of cat caudate neurons. Brain Res 192:441-462.

Higashi H, Inanaga K, Nishi S, Uchimura N (1989) Enhancement of dopamine actions on rat nucleus accumbens neurones in vitro after methamphetamine pre-treatment. J Physiol (Lond) 408:587-603.

Horikawa K, Armstrong WE (1988) A versatile means of intracellular labeling, injection of biocytin and its detection with avidin conjugates. J Neurosci Methods 25:1-11.

$\mathrm{Hu}$ X-T, White $\mathrm{F}$ (1994) Loss of $\mathrm{D}_{1} / \mathrm{D}_{2}$ dopamine receptor synergisms following repeated administration of $\mathrm{D}_{1}$ or $\mathrm{D}_{2}$ receptor selective antagonists: electrophysiological and behavioral studies. Synapse 17:43-61.

Huang Y-Y, Kandel ER (1995) D1/D5 receptor agonists induce a protein synthesis-dependent late potentiation in the CA1 region of the hippocampus. Proc Natl Acad Sci USA 92:2446-2450.

Kawaguchi Y, Wilson CJ, Emson PC (1989) Intracellular recording of identified neostriatal patch and matrix spiny cells in a slice preparation preserving cortical inputs. J Neurophysiol 62:1052-1068.

Kebabian JW, Britton DR, DeNinno MP, Perner R, Smith L, Jenner P, Schoenleber R, Williams M (1992) A-77636: a potent and selective dopamine $\mathrm{D}_{1}$ receptor agonist with antiparkinsonian activity in marmosets. Eur J Pharmacol 229:203-209.

Knapp AG, Schmidt KF, Dowling JE (1990) Dopamine modulates the kinetics of ion channels gated by excitatory amino acids in retinal horizontal cells. Proc Natl Acad Sci USA 87:767-771.

Law-Tho D, Hirsch JC, Crepel F (1994) Dopamine modulation of synaptic transmission in rat prefrontal cortex: an in vitro electrophysiological study. Neurosci Res 21:151-160.

Levey AI, Hersch SM, Rye DB, Sunahara RK, Niznik HB, Kitt CA, Price DL, Maggio R, Brann MR, Ciliax BJ (1993) Localization of $\mathrm{D}_{1}$ and $\mathrm{D}_{2}$ dopamine receptors in brain with subtype-specific antibodies. Proc Natl Acad Sci USA 90:8861-8865.

Levine MS, Cepeda C, Day M, Altemus KL, Li Z (1995) Dopaminergic modulation of responses evoked by activation of excitatory amino acid receptors in the neostriatum is dependent upon specific receptor subtypes. In: Cellular and molecular mechanisms of the striatum (Ariano MA, Surmeier DJ, eds), pp 217-228. Georgetown, TX: Landes.

Levine MS, Li Z, Cepeda C, Cromwell HC, Altemus KL (1996) Neuromodulatory actions of dopamine on synaptically-evoked neostriatal responses in slices. Synapse, in press.
Mercuri N, Bernardi G, Calabresi P, Cotugno A, Stanzione P (1985) Dopamine decreases cell excitability in rat striatal neurons by pre- and postsynaptic mechanisms. Brain Res 358:110-121.

Miner LL, Drago J, Chamberlain PM, Donovan D, Uhl GR (1995) Retained cocaine conditioned place preference in $\mathrm{D}_{1}$ receptor deficient mice. NeuroReport 6:2314-2316.

Misgeld U, Weiler MH, Bak IJ (198) O) Intrinsic cholinergic excitation in the rat neostriatum: nicotinic and muscarinic receptors. Exp Brain Res 39:401-407.

Monsma Jr FJ, Mahan LC, McVittie LD, Gerfen CR, Sibley DR (1990) Molecular cloning and expression of $\mathrm{a}_{1}$ dopamine receptor linked to adenylate cyclase activity. Proc Natl Acad Sci USA 87:6723-6727.

Nicola SM, Kombian SB, Malenka RC (1996) Psychostimulants depress excitatory synaptic transmission in the nucleus accumbens via presynaptic $D_{1}$-like dopamine receptors. J Neurosci 16:1591-1604.

Nisenbaum ES, Berger TW, Grace AA (1993) Depression of glutamatergic and GABAergic synaptic responses in striatal spiny neurons by stimulation of presynaptic GABA $_{\mathrm{B}}$ receptors. Synapse 14:221-242.

Noblett KL, Ariano MA (1996) Coexpression of receptor mRNA and protein: striatal dopamine and excitatory amino acid subtypes. J Neurosci Methods 66:61-67.

Pennartz CM, Dolleman-Van der Weel MJ, Kitai ST, Lopes da Silva FH (1992) Presynaptic dopamine D1 receptors attenuate excitatory and inhibitory limbic inputs to the shell region of the rat nucleus accumbens studied in vitro. J Neurophysiol 67:1325-1334.

Pereda A, Nairn AC, Wolszon LR, Faber DS (1994) Postsynaptic modulation of synaptic efficacy at mixed synapses on the Mauthner cell. J Neurosci 14:3704-3712.

Pereda A, Triller A, Korn H, Faber DS (1992) Dopamine enhances both electrotonic coupling and chemical excitatory postsynaptic potentials at mixed synapses. Proc Natl Acad Sci USA 89:12088-12092.

Seasack SR, Aoki C, Pickel VM (1994) Ultrastructural localization of $\mathrm{D}_{2}$ receptor-like immunoreactivity in midbrain dopamine neurons and their striatal targets. J Neurosci 14:88-106.

Smith AD, Bolam JP (1990) The neural network of the basal ganglia as revealed by the study of synaptic connections of identified neurones. Trends Neurosci 13:259-265.

Smith DO, Lowe D, Temkin R, Jensen P, Hatt H (1995) Dopamine enhances glutamate-activated currents in spinal motoneurons. J Neurosci 15:3905-3912.

Stoof JC, Kebabian JW (1981) Opposing roles for D-1 and D-2 dopamine receptors in efflux of cyclic AMP from rat neostriatum. Nature 294:366-368.

Walsh JP, Hull CD, Levine MS, Buchwald NA (1989) Kynurenic acid antagonizes the excitatory post-synaptic potential elicited in neostriatal neurons in the in vitro slice of the rat. Brain Res 480:290-293.

$\mathrm{Xu} \mathrm{M,} \mathrm{Moratalla} \mathrm{R,} \mathrm{Gold} \mathrm{LH,} \mathrm{Hiroi} \mathrm{N,} \mathrm{Koob} \mathrm{GF,} \mathrm{Graybiel} \mathrm{AM,}$ Tonegawa $S$ (1994a) Dopamine $\mathrm{D}_{1}$ receptor mutant mice are deficient in striatal expression of dynorphin and in dopamine-mediated behavioral responses. Cell 79:729-742.

Xu M, Hu X-T, Cooper DC, Moratalla R, Graybiel AM, White FJ, Tonegawa S (1994b) Elimination of cocaine-induced hyperactivity and dopamine-mediated neurophysiological effects in dopamine $\mathrm{D}_{1 \mathrm{~A}}$ receptor mutant mice. Cell 79:945-955.

Xu M, Caine SB, Cooper DC, Gold AM, Graybiel AM, Hu X-T, Koeltzow TE, Koob G, Moratalla R, White FJ, Tonegawa S (1995) Analysis of dopamine $\mathrm{D}_{3}$ and $\mathrm{D}_{1}$ receptor mutant mice. Soc Neurosci Abstr 21:363.

Yung KKL, Bolam JP, Smith AD, Hersch SM, Ciliax BJ, Levey AI (1995) Immunocytochemical localization of $\mathrm{D}_{1}$ and $\mathrm{D}_{2}$ dopamine receptors in the basal ganglia of the rat: light and electron microscopy. Neuroscience 65:709-730. 